\title{
Ecology and Biogeography of the Ground Fauna of Suez Canal Region
}

\author{
Esraa S. Hamdy ${ }^{1^{*}}$, Shereen M. Elbanna ${ }^{2}$, Ahmed H. Abo Ghalia ${ }^{2}$, Ahmed A. Shabayek ${ }^{3}$ \\ ${ }^{1}$ Nature Conservation Sector, Egyptian Environmental Affairs Agency, Ministry of Environment, Egypt \\ ${ }^{2}$ Department of Zoology, Faculty of Science, Suez Canal University, Ismailia, Egypt \\ ${ }^{3}$ Department of Land and Water, Faculty of Agriculture, Suez Canal University, Ismailia, Egypt
}

\begin{abstract}
Ground invertebrate fauna is the most diverse and important group to maintain the soil health. The Suez Canal region has a unique status in Egypt. Since the opening of Suez Canal for international navigation in 1869, population in the Canal region increased and green areas expanded. The expanded cities have initiated new habitats and attracted some taxa from the Nile valley to the west bank of the Suez Canal. This study is an attempt to investigate the distribution pattern of ground-macroinvertebrates in correlation with land-use along the west bank of Suez Canal in a considerable region. The faunal samples were collected using pitfall traps in 9 sites belonging to 3 stations; Abusultan, Fanara and Geneifa, with different land use practices (natural desert, agricultural areas and urbanized coast). A number of 3502 arthropod individuals belong to 129 species were recorded. The highest species richness was shown by Coleopterans, while the most abundant group was Hymenoptera. The agricultural and the urbanized coastal sites have shown significantly lower abundance of ground macro-invertebrates in comparison with the natural desert habitats. It was concluded that urbanization and agricultural practices have altered soil properties, thus they adversely affected the abundance of ground invertebrate assemblage.
\end{abstract}

Keywords: Agricultural practices, Coleopterans, Ground fauna, Habitats, Hymenoptera, Macroinvertebrates, Urbanization, Pitfall traps, Suez Canal region.

\section{INTRODUCTION}

As of being the junction of four biogeographical regions: Mediterranean, Irano-Turanian, Afrotropical and Saharo-Sindian, and divided longitudinally by the Nile, Egypt is characterized by a variety of eco-zones. As a result, the country is home to a diversity of terrestrial habitats, fauna and flora, which are extremely varied in composition (Winer, 1999 and Mikhail, 2002). However, Egypt is facing a challenge of getting the balance between the increased population needs to the biodiversity and the conservation aspects in the view of the barren nature of most lands and the consequences of climate change and human activities. Therefore, the country's natural resources are under threat due to the increasing loss of biodiversity combined with on going desertification and habitat loss (Egypt heritage, 2015).

Among the described global animal species (about one million, three hundreds and five thousands and two hundred and fifty species), invertebrates constitute the majority (over 1.2 million species). Arthropods are the most abundant and diverse group of fauna in most ecosystems. Soil macro invertebrate fauna assemblages are mostly living on the surface layer of soil, thus they are referred to as "ground fauna". Scientists estimate that one-quarter of the earth's species live in soil. However, this is not reflected well in the ecological studies concerning soil fauna. Soil organisms are characterized by not only the direct involvement in biological processes or being facilitators of many of them, but also by the high sensitivity to several stressors. Therefore, they are widely used as indicators to assess the quality of the soil (The IUCN Red List of Threatened Species, 2010; Finnamore et al., 1998; Jeffery et al., 2010). The knowledge and data readily available about soil-dwelling fauna is a poor reflection biogeographic data (Durrant, 2009).

Effective management and conservation of biodiversity depends mainly on the basic knowledge of community composition, ranging from the richness patterns and distribution of species to the ecological functions of species in the community. Unfortunately, the world's knowledge about biodiversity is still limited. According to the Convention on Biological Diversity (CBD), "only one out of five to ten of all species is known to science". Some faunal groups, mostly arthropods, many species still unknown beside the data about distribution and diversity of most of species (CBD, 2015). The Suez Canal region has a special and unique status in Egypt. Since the opening of Suez Canal for international navigation in 1869 , population in the Canal region increased and green areas expanded widely. The expanded cities have initiated new habitats that attracted some taxa from the Nile valley to the west bank of the Suez Canal. How-ever, the military actions that the Suez Canal zone had exposed resulted in giving a little attention for the ecological studies concerning biodiversity in this area (Ibrahim, 2013).

Therefore, this work aimed to investigate the ground macro-invertebrate fauna of Suez Canal region in the view of some environmental characteristics using spatial technologies for better understanding of the species habitats. The effect of the pattern of land use and the degree of human intervention on populations of invertebrate ground fauna were also considered.

\footnotetext{
* Corresponding author: esraa.eeaa@gmail.com
} 


\section{MATERIALS AND METHODS}

\section{Study area}

This study was conducted in Suez Canal region along the west bank of Suez Canal and includes the northern part of Suez Governorate and the southern part of Ismailia Governorate (at N30.41046, E32.32851 - N30.23229, E32.457
44) (Fig. 1). The Maximum true altitude is $44 \mathrm{~m}$ above sea level, whereas the minimum true altitude is $16 \mathrm{~m}$ above sea level. This region is characterized by an arid climate with a maximum temperature of $36.1^{\circ} \mathrm{C}$ in July and a minimum temperature $7.8^{\circ} \mathrm{C}$ in January. The average annual temperature is about $21.5^{\circ} \mathrm{C}$. The average annual precipitation is $33.3 \mathrm{~mm}$ (Ghabbour, 1993).

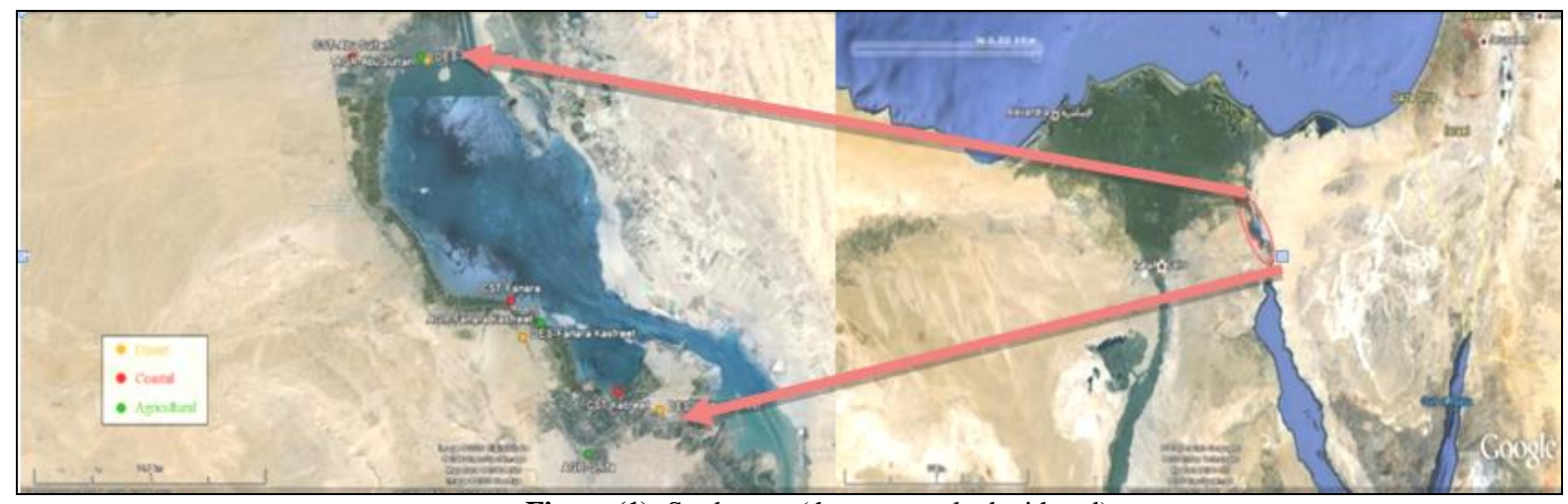

Figure (1): Study area (the area marked with red).

The study area at the west side of Ismailia-Suez road where natural desert habitats as well as habitats under land use pressures are represented. Agriculture and urbanization of the coast are the main land use practices in the study area. It was required to select sites repressenting 3 habitats of different land use (natural desert, agricultural areas, and urbanized coast). All these habitats are available and accessible along the west side of Ismailia-Suez. The selected area is restricted to the region between Abu Sultan and Geneifa.

In the selected study area, 3 stations were chosen to trap ground-dwelling fauna: Abu Sultan, Fanara and Geneifa (Fig. 1). Each one of them contains the 3 required types of habitats. Three sites were chosen in each station to put the traps which are representatives to natural desert, agricultural, and urbanized coastal habitats. The 9 sites within the different 3 stations were chosen according to: Accessibility, Out of reach, Sustainability and representativeness (costal, agricultural and desert sites).

\section{Collection: Pitfall Trapping}

Pitfall trapping is the method of collecting epigeic invertebrate animals by putting open containers in the ground (Brussaard et al, 2006). This method is a useful tool in estimating the abundance and composition of ground active invertebrate assemblages in an area (Harhash, 2003).

A number of 54 jars were used as pitfall traps, 6 for each site compromising 18 for each station and each habitat type. Coordinates were taken for the location of each trap and for the whole area as well using GPS. Traps were filled by water with a detergent solution (1\%) to ensure rapid sinking of animals and kept open for 3 days then collected. Ground active macrofauna were collected seasonally, from autumn 2010 to summer
2011 and every three months, in October, January, April and July. The content of each trap was examined by means of binocular microscope; animals picked up and preserved in vials filled with $70 \%$ ethanol. The preserved fauna specimens were identified with the help of specialists.

\section{Plant Sampling and Identification}

Specimens of the plants in the study area were collected and photographed before being identified according to (Boulos 1995, 1999, 2000, 2002 and 2005).

\section{Soil Sampling and Analysis}

During the spring time (April), samples for soil surface (about $20 \mathrm{~cm}$ ) and plant cover in all the 9 sites of the study area were collected. The collected soil samples were air-dried, crushed and sieved to pass through a $2 \mathrm{~mm}$ sieve. Then, they were taken to the laboratory of Soil Department in the faculty of Agriculture to be analyzed against physical and chemical properties: salinity, texture, electric conductivity, organic matter, $\mathrm{pH}$, moisture, cations and anions, total nitrogen, phosphorus and potassium according to standard methods (Page et al., 1982).

\section{Data Analysis:}

The resulted data, corresponding the collected faunal species and soil samples during the practical work of the study, were manipulated using Microsoft Excel 2010 and PC-ORD " 5 " programs for multivariate analysis. Ground fauna diversity was expressed as species richness and abundance.

Analyses of variance (ANOVA) were used to test for differences in spatial values of abundance and species richness between the different study sites with different land use practices. Sorenson's coefficient has been cho- 
sen to calculate the similarity between communities.

It attains a maximum value of 1.0 when all species present in one sample are also present in the other samples. Classification (TWINSPAN) and ordination (DC-ORANA) and (CANOCO) of the 9 sites of this study in the view of ground faunal species, plant species and soil chemical and physical properties were carried out by PC-ORD 5 windows based program. (Hill et al., 2013; McCune and Mefford, 1999).

\section{RESULTS}

\section{Species richness and abundance in the study area}

Due to the large number of invertebrate fauna types involved in soil ecosystem, this investigation is limited to ground macro-invertebrate fauna. It concerns with the arthropods collected by pitfall traps which are characterized by a body size greater than $2 \mathrm{~mm}$. According to this study, a number of 3502 individuals were found belong to 129 species, compromising fifteen groups. Among 129 species found during this study, 38 species were belonging to Coleoptera, 30 species of Spiders and 23 species of Hymenopterans (from which 14 species are formicids).

The total recorded number of individuals collected was 2322 Hymenopterans, 245 Coleopterans and 208 spiders. The most important groups according to the numbers of both species and individuals are Orders Hymenoptera (Family Formicidae), Coleoptera and Aranae. The highest species richness was shown by Coleopterans (Fig. 2) while the most abundant group is Hymenoptera (Fig. 3).

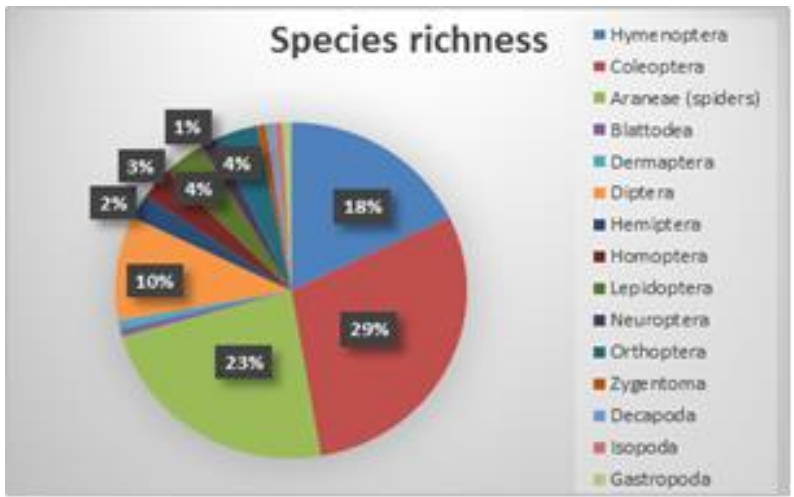

Figure (2): Total numbers of species of the ground fauna groups in the study area.

\section{Abundance in the three habitats}

The abundance of ground fauna in the three different habitats (desert, agricultural and coastal habitats) is shown in figure (4). ANOVA analysis shows a very high significant difference between the abundance values of ground invertebrate species in the three habitats $(\mathrm{p}<0.01)$, with very high abundance in desert habitat in comparison with the other two habitats (which show a little variation with each other).

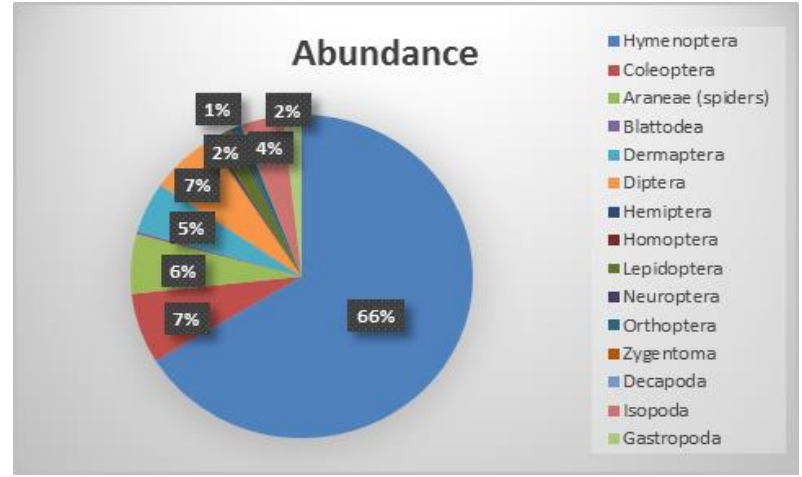

Figure (3): Total numbers of individuals of ground fauna groups in the study area.

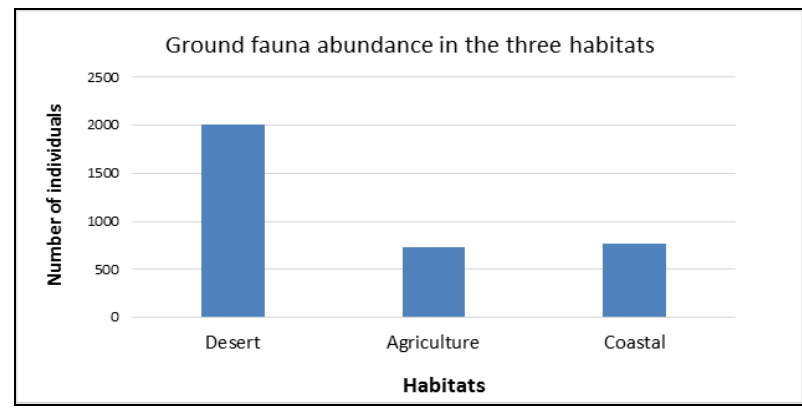

Figure (4): Ground fauna abundance in the three habitats

\section{Species richness in the three habitats}

According to figure (5) the highest species richness of all the three habitats of the study is in desert and the lowest is in the agricultural habitat. ANOVA analysis illustrated that there is no significant difference between the species richness of ground fauna in the three habitats (desert, agricultural and coastal habitats) $(\mathrm{P}>0.05)$.

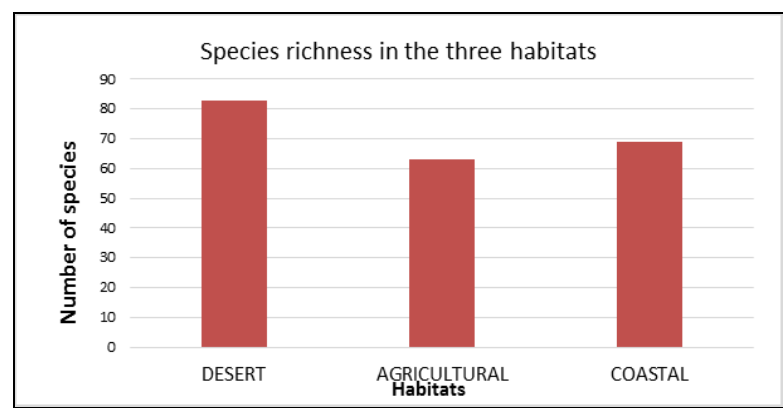

Figure (5): Species richness in the three habitats

\section{Similarity among Ground Invertebrate Fauna Com- munities}

Calculating similarity using Sorenson's coefficient

Sorenson's coefficient gives a value between 0 and 1 , the closer the value is to 1 , the more the communities have in common. Complete community overlap is equal to 1 ; complete community dissimilarity is equal to 0 .

Table (1) shows the similarity between ground fauna communities of the three habitats. Desert and agricultural habitats show the highest similarity between grou- 
nd fauna communities ( $\mathrm{CC}=0.58)$, communities in desert and coastal areas are less similar to each other $(\mathrm{CC}=$ 0.52 ) while those of coastal and agricultural areas are least similar $(\mathrm{CC}=0.48)$.

Table (1): Similarity coefficient of ground fauna communities of the three habitats

\begin{tabular}{llll}
\hline \hline \multicolumn{1}{c}{ Habitat } & $\begin{array}{l}\text { Desert } \\
\text { sites }\end{array}$ & $\begin{array}{l}\text { Agricultural } \\
\text { sites }\end{array}$ & $\begin{array}{l}\text { Coastal } \\
\text { sites }\end{array}$ \\
\hline Desert sites & 1 & 0.58 & 0.52 \\
Agricultural sites & 0.58 & 1 & 0.48 \\
Coastal sites & 0.52 & 0.48 & 1 \\
\hline \hline
\end{tabular}

\section{Multivariate Analysis}

Classification: Two Way INdicator SPecies ANalysis (TWINSPAN)

The classification of the nine sites of the study area according to the ground faunal species using TWINSPAN showed a number of four cluster groups based on three levels of division as illustrated in the dendrogram (Fig. 6). At the first level of division, FD site (Fanara Desert) was separated from the other eight sites in a cluster group (1) using a species from family formicidae as an indicator for the negative group, Monomorium mayri. The coastal sites (AC, FC and GC) have been in a separate group at the second division level, in the negative side for which the formicid species Cataglyphis holgerseni was an indicator. The third level of division has divided the five remaining sites into two grou$\mathrm{ps}$, one of them is in the positive site including the two desert sites (AD and GD) and the other is in the negative side including the three Agricul-tural sites (AA, FA and GA). The ant species, Cremat-ogaster aegyptiaca, was an indicator for the positive side group (011) in the third division.

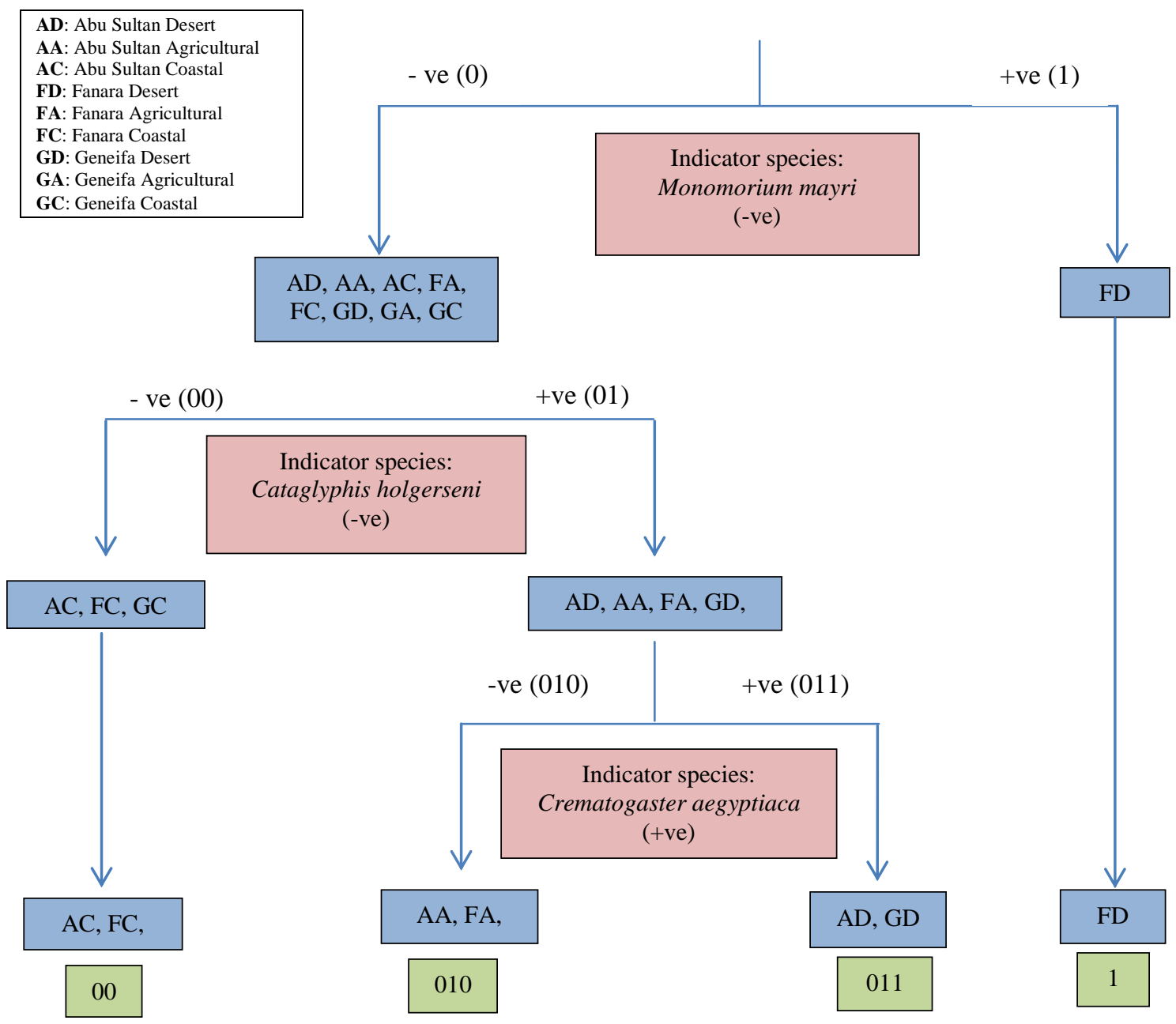

Figure (6): A dendrogram showing the classification of the nine sites of the study using TWINSPAN into four cluster groups. 


\section{Ordination: Detrended Correspondence Analysis} (DCA)

The ordination of the nine study sites according to the collected species DECORANA showed that the sites were clustered and arranged in the space between two axes. Fanara desert was arranged in a separate group, while the other two sites of the agricultural habitats (Abusultan desert and Geneifa desrt) were arranged apart from it which means that they are closely related with each other than FD. The coastal sites (Abusultan coastal, Fanara coastal and Geneifa coastal sites) were arranged in one group, however it is clear that (AC and GC) are closer to each other and slightly away from $\mathrm{FC}$. The same thing for the agricultural sites (Abusultan agricultural, Fanara agricultural and Geneifa agricultural sites) they are in one group, but the two sites AA and FA were arranged close to each other and away from GA which is a reclaimed farmland (Fig. 7)

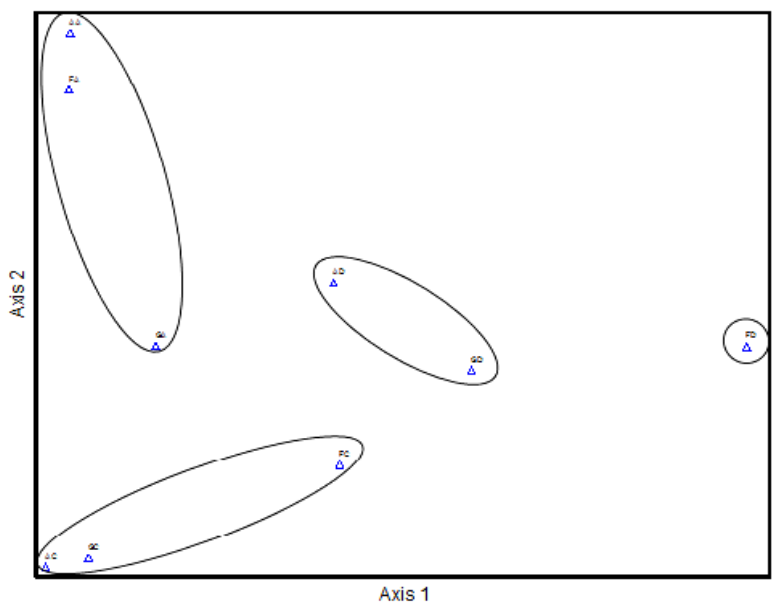

Figure (7): A graph resulted from Detrended Correspondence Analysis (DCA or DECORANA) for the ordination of the study area sites.

\section{Canonical Correspondence Analysis (CCA)}

The environmental variables used in this work are the plant cover and soil physical and chemical parameters. In figure (8) the most effective factors among plant species and soil physical and chemical properties were selected. It is clear that some of properties have weak effect (indicated by the short arrows). The factors of plant coverage are a characteristic of the three desert sites and FC site (Fanara coastal site), however the two other coastal sites are characterized by ornamental plants and the agricultural sites are planted by crop plants. The most effective plant species were Tamarix aphylla (L.) H. Karst., Pituranthos tortuosus, Pergularia tomentosa, Arthrocnemum macrostachyum, Astragalus spinosus (forssk.) Muschl., Crotalaria aegyptiaca Benth., Acacia nilotica (L.) Delile, Alhagi graecorum Boiss., Zygophyllum album and Zygophyllum coccinum.

According to soil properties, it is obvious that the parameters of total Soil Organic Matter (Tot SOM) and total organic matter (Tot Org) are the strongest factors. They characterize the agricultural sites, specifically AA and FA sites, with the factors of clay, moisture, the ratio of Carbon/Nitrogen $(\mathrm{C} / \mathrm{N})$ and the ratio of Carbon/ Phosphorus $(\mathrm{C} / \mathrm{P})$. GA site is more salty and the effect of the previous factors is lesser on it. Coastal sites are sandy to silty (FC is more sandy while AC and GC are more silty), and characterized by the effect of potassium (K) on them (especially on FC). The desert sites (AD, FD and GD) are affected by the calcium carbonate $(\mathrm{CaCO} 3)$ and the sandy texture. $\mathrm{pH}$ increases in the agricultural sites (AA, FA and GA) and also two of the coastal sites (AC and GC).

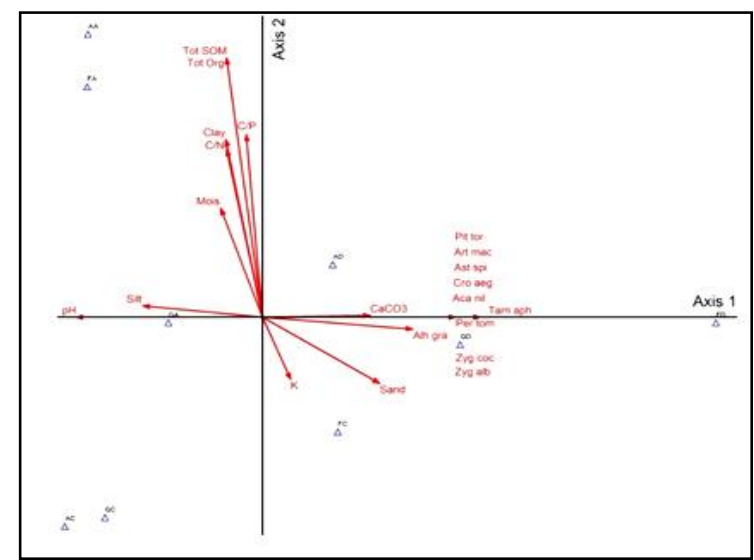

Figure (8): The effect of soil physical and chemical parameters and plant cover on the nine sites of the study area.

\section{DISCUSSION}

The variation in Egypt ecoregions and land use practices has proven impact on ground fauna abundance and species diversity. Changing the use of land will has either negative or positive impact on the soil structure, which is the shelter of many groups of arthropods. The impact of land use changes can lead to favourable conditions for certain ecosystem services or to the degradation and even loss of soil (Defra, 2009).

This study focuses on ground arthropods community structure in one of the natural habitats which exposed to habitat alteration in the previous few decades. This is due to the conversion of Suez Canal region from being a neglected and destroyed area to the great recent economic development. According to which, Suez Canal region can be an attractive land for many faunal species and in the same time habitat alteration has an effect on fauna.

Through studying the ecology and distribution pattern of various macro ground-dwelling invertebrate fauna in Suez Canal region in the present study, it was illustrated that the most important groups are order Hymenoptera, especially family Formicidae, order Coleoptera and Order Araneae (spiders).

They are represented by large numbers of both species and individuals in ground fauna assemblage recorded in the study area. Many ecological studies on soil fauna communities locally, nationally and internationally have revealed the importance of ants (Mikhail, 1993; Doblas-Miranda et al., 2007; El Surtasi et al., 2011 and El Bokl et al., 2015), ground beetles (Mikhail, 1993; Semida et al., 2001; 
Doblas-Miranda et al., 2007; El Surtasi et al., 2011 and 2012; Mahbob and Mahmoud, 2013; and Elnamrouty, 2014), and spiders (Mikhail, 1993; Medany, 2013; and Elnamrouty, 2014) and investigate their response to various environmental factors. The total abundance of the collected ground arthropods was relatively low (3502 individuals), but the species richness is relatively high (129 species). Most species collected and identified during this study were commonly found in other parts of Egypt. It was found that some species were collected regularly, while others were rare within one site or the whole area of the study. This is consistent with the results of other community studies, which show that a small number of species dominates the community, while large number of species are relatively rare or even represented by one individual (El-Moursy et al., 1999 and 2001). The most abundant species found, with great numbers in the Suez Canal region, are formicid species (2236 individuals). Most of them were found in large numbers in comparison with the other species.

The results of this study showed that the most abundant sites were the desert ones which represent the natural habitats of the region with lowest human impacts. Urbanized and agricultural sites are significantly low in ground fauna abundance in comparison with natural desert habitats. Agricultural sites also showed the lower levels of species richness. The reason for these results could be explained by the continuing drive of human impacts to natural systems to the direction of increasing patchiness and variability. These patchy habitats can affect ecological patterns and processes (MacArthur and Wilson's, 1967). Soils in urban areas are generally considered as highly disturbed and heterogeneous, with little systematic pattern in their characteristics (Pouyat et al, 2010). Urbanization, as a change in land use, can alter the physical and chemical properties of the soil. This will lead to a habitat disturbance for micro, meso and macrofauna of the soil. Changed soil conditions can affect the functionality of individual soil biota, as well as determine their presence or absence in a community (De Ruiter et al., 2002). Agricultural activities have either positive or negative influence on diversity, abundance and activity of soil fauna according to the chemical properties of soil and the alteration of natural habitat to agricultural land. Agricultural practices can be both beneficial and detrimental to soil invertebrates (Rizk and Mikhail, 1999).

TWINSPAN analysis and Detrended Correspondence Analysis (DCA) have differentiated among the sites of the same habitat with each other. The classification process proceeded in 3 levels. The first level separated the site (4) community than the other 9 sites. This site is Fanara desert which is characterized by a significant higher abundance of ground invertebrate fauna. It was also the lowest site in human pressure, land use and habitat alteration.

The second level of division has separated the coastal sites in one group from the other group which included agricultural and desert sites. The result of this separation illustrates that natural ecosystems represented by the desert habitats are similar to each other and more similar to the agricultural sites than the urbanized coastal ones. This is consistent with the result of similarity test among communities of ground fauna (Sorenson's Coefficient). The highest value of similarity coefficient among communities of the different habitats was between agricultural and desert habitats $(\mathrm{CC}=0.58)$. Earlier studies supported this conclusion (Ghabbour and Mikhail 1993a, 1993b and Hanna et al, 2012). The third level of division resulted in separating the remaining desert sites from the agricultural sites.

According to Detrended Correspondence Analysis, Abu Sultan and Fanara agriculture (sites 2 and 5) are more similar to each other in the view of ground fauna community. However, Geneifa agriculture (site 8) is less similar to them and far from them. It is not strange result because Abu Sultan and Fanara agriculture are typical cultivated lands, while Geneifa agriculture is a newly reclaimed land. On the other hand, the communities of Abu Sultan and Geneifa coastal sites (sites 3and 9) are more similar and closer to each other than Fanara coastal site (site 6), which is less effected by urbanization. This is also normal because Abu Sultan and Geneifa coastal sites are urbanized sites, but Fanara coastal site is a military place with less urbanization impact.

Canonical Correspondence Analysis (CCA) showed that the most effective soil properties that affect the differentiation of the sites are those associated with the agricultural practices, especially the soil organic matter (SOM) and the total organic matter. They were greatly increased in the agricultural land, in particular in Abu Sultan and Fanara. As a consequence, the factors of SOM total organic matter are accompanied by related factors such as clay percentage, moisture, the ratio of Carbon/Nitrogen and the ratio of Carbon/Phosphorus. Soil organic matter (SOM) has a great effect on soils. It increases the capacity of soils to bind chemicals, improves soil structure and water infiltration and retention, buffers the releases of pollutants, regulates the supply of nutrients and makes the soil more resistant to drought and erosion (Defra, 2009).

Soil structure was one of the most important factors. Geniefa agricultural site is the sandiest agricultural one, desert sites are affected by the sandy texture, as well as coastal sites. Coastal sites are characterized by the effect of decreased levels of Potassium, however the desert sites are affected by the higher levels of calcium carbonate $\left(\mathrm{CaCO}_{3}\right) \cdot \mathrm{pH}$ increases in two of the agricultural sites ( $\mathrm{Abu}$ Sultan and Fanara), and also the coastal sites (especially those in Abu Sultan and Geneifa), exceeding the edge of 8 . Plant growth and most soil processes, including nutrient avail-ability and biotic activities, are favored by a soil $\mathrm{pH}$ ranging from 5.5 to 8 (Soil quality, 2016). Over or below this range, soil begins to be unhealthy. These results indicate that each type of habitat has its own soil composition with different factors affecting them. This difference has been resulted in the variation of ground fauna abundance with the greatest values in natural desert habitats and diminished values in the other impacted sites, especially agricultural habitats.

The factors of plant coverage are a characteristic of the 
three desert sites and one coastal site (Fanara), however the two other coastal sites are characterized by ornamental plants, whereas the agricultural sites are planted by crop plants. The most effective plant is Tamarix aphylla which was found to be behind the increased abundance of Abu Sultan desert site.

\section{CONCLUSION}

According to the present study, Suez Canal region is rich in ground invertebrate fauna that may include undiscovered species. Data available about ground invertebrates in Suez Canal region is still poor. This area is also under the pressure of the continuous development and increased human activities. Urbanization and agricultural practices showed an adverse effect on ground fauna abundance in the study area. Therefore, more ecological studies concerning ground invertebrate fauna and their response to habitat alteration in Suez Canal region are required.

\section{ACKNOWLEDGEMENT}

This work could have not been achieved without the collaboration of Mr. Hisham Elhennawy, Arachnid Collection of Egypt; Prof. Mahmoud Saleh Abdel-Dayem, Professor of Insect taxonomy and biodiversity, Faculty of science, Cairo University; Dr. Mostafa Sharaf, Assistant Prof., college of food sciences and agriculture, king Saud University, Riyadh; and Dr. Mohamed Talaat El-Hennawy, the former Director of Protected Areas Department, Egyptian Environmental Affairs Agency. I thank them deeply for their help in species taxonomy and identification of spiders, beetles, ants and plants.

\section{REFERENCES}

BOULOS L. 1995. Flora of Egypt checklist, Al-Hadra Publishing, Cairo, Egypt.

BOULOS L. 1999. Flora of Egypt vol. 1, Al-Hadra Publishing, Cairo, Egypt.

BOULOS L. 2000. Flora of Egypt Vol. 2, Al-Hadra Publishing, Cairo, Egypt.

BOULOS L. 2002. Flora of Egypt Vol. 3, Al-Hadra Publishing, Cairo, Egypt.

BOULOS L. 2005. Flora of Egypt Vol. 4, Al-Hadra Publishing, Cairo, Egypt.

BRUSSAARD L., J. O. SIQUEIRA, AND F. M. S. MOREIRA. 2006. Soil biodiversity in Amazonian and other Brazilian ecosystems. CABI Publishing: $280 \mathrm{pp}$.

CBD (CONVENTION ON BIOLOGICAL DIVERSITY). Status and Trends of Global Biodiversity. Available from: https://www.cbd. int/ gbo1/chap01.shtml [Accessed 5 December, 2015].

DE RUITER, P. C., B. GRIFFITHS, AND J. C. MOORE, 2002. Biodiversity and stability in ecosystems: patterns, processes and the effect of disturbance. In: Loreau, M., Naeem, S., Inchausti, P. (Eds.), Biodi- versity and Ecosystem Functioning: Synthesis and Perspectives. Oxford University Press Oxford: 102113.

DEFRA 2009. SOIL STRATEGY FOR ENGLAND: Supporting Evidence Paper. Department for Environment, Food and Rural Affairs.

DOBLAS-MIRANDA E., F. SA' NCHEZ-PIN ${ }^{\sim}$ ERO, AND A.GONZA' LEZ-MEGI'AS 2007. Soil macroinvertebrate fauna of a Mediterranean arid system: Composition and temporal changes in the assemblage. Soil Biology and Biochemistry 39: 19161925.

DURRANT B. 2009. Terrestrial invertebrate biodiversity assessment for the Gnangara sustainability strategy. Department of Environment and Conservation, Woodvale WA 6026, Final report: 48 pp.

EGYPT HERITAGE. 2015. Egyptian Biodiveristy. http://www.egyptheritageCom/BiodiversitySite/inde x. html [Accessed 16 November, 2015].

EL BOKL M. M., F. M. SEMIDA, M. S. ABDELDAYEM, AND E. I. EL SURTASI. 2015. Ant (Hymenopter: Formicidae) diversity and bioindicators in the lands with different anthropogenic activities in New Damietta, Egypt. Int. J. Entomol. Res. 3 (2): 35-46.

EL SURTASI E. I., F. M. SEMIDA, M. S. ABDELDAYEM, AND M. M. EL BOKL. 2012. The Threat of Urbanization on Beetle Diversity in New Damietta City, Egypt. Nature and Science 10 (1): 15-23.

EL SURTASI E. I., M. M. EL BOKL, F. M. SEMIDA, AND ABDEL-DAYEM M. S. 2011. Impact of anthropogenic activities on the ground insect's biodiversity in New Damietta region, Egypt. Academic Journals 5 (7): 125-132.

EL-MOURSY A. A., F. GILBERT, S. ZALAT, AND M. S. EL-HAWAGRY. 1999. Foraging behavior of anthracine flies (Diptera: Bombyliidae) in Southern Sinai, Egypt. Egyptian Journal of Biology 1: 87-95.

EL-MOURSY A., M. EL-HAWAGRY, M. S. ABDELDAYEM, AND H. FADL. 2001. Insect diversity in Zaranik protectorate, North Sinai, Egypt. Egyptian Journal of Natural History 3: 62-80.

ELNAMROUTY S. O. M. 2014. Importance of some invertebrate fauna in environmental impact assessment in Ashtoum Elgamail Natural Protected Area. M. Sc. Thesis, Dept. of Zoology, Faculty of Science, Suez Canal University: 154 pp.

Fact Sheets Soil Acidity. Soil Acidity http://soil quality.org.au/factsheets/soil-acidity. [Accessed 13 October 2016].

FINNAMORE A. T., N. N. WINCHESTER, AND V. M. BEHAN-PELLETIER. 1998. Protocols for measuring biodiversity: arthropod monitoring in terrestrial ecosystems. Biodiversity Science Board of Canada, Ecological Monitoring and Assessment Network, Burlington, Ontario.

GHABBOUR S. I., AND D. GOLANI. 1993. The sandy shore of the red sea-Launching pad for lessepsian (Suez Canal) migrant fish colonizers of the eastern 
Mediterranean. Journal of Biogeography 20(6): 579585.

GHABBOUR S. I., AND W. Z. A. MIKHAIL. 1993a. Habitat classification using soil fauna populations. Publications of the National Biodiversity Unit 1: 203-236.

GHABBOUR S. I., AND W. Z. A. MIKHAIL. 1993b. Diversity of soil fauna in Egypt. Mesogee 53: 21-53.

HANNA S. H. S., S. I. GHABBOUR, W. Z. A. MIKHAIL, H. M. SOBHY, AND G. SULTAN. 2012. Diversity of functional groups of soil fauna in Egyptian habitats. International Journal of Environmental Science and Engineering (IJESE) 3: 49-70

HARHASH K. A. 2003. Studies on population dynamics of invertebrates in Taba protected area. M. Sc. Thesis, Dept. of Zoology, Faculty of Science, Cairo University.

HILL M. O., C. A. HARROWER, AND C. D. PRESTON. 2013. Spherical k-means clustering is good for interpreting multivariate species occurrence data. Methods in Ecology and Evolution 4 (6): 542-551.

IBRAHIM A. A. 2013. The Herpetology of the Suez Canal Zone, Egypt. Vertebrate Zoology 63 (1): 87110.

JEFFERY S., C. GARDI, A. JONES, L. MONTANARELLA, L. MARMO, L. MIKO, K. RITZ, G. PERES, J. RÖMBKE, AND W. VAN DER PUTTEN H. 2010. European atlas of soil biodiversity. European Commission, Publications Office of the European Union, Luxembourg: 128 pp.

MACARTHUR R., AND E. O. WILSON. 1967. The theory of island biogeography. Princeton University Press, Princeton, NJ.

MAHBOB M. A., AND H. H. MAHMOUD. 2013. The first report of preliminary list of the insect fauna of the Elkharaga city, New Valley, Egypt. Journal of Ecology and the Natural Environment, Full Length Research Paper.

MCCUNE B., AND M. J. MEFFORD. 1999. PC-ORD.
Multivariate analysis of Ecological Data, Version 4.0 for Windows. MjM Software, Gleneden Beach, Oregon, USA.

MEDANY D. M. A. 2013. Spiders as bioindicator for environmental risk assessment of woody forest plantation in Serabium region, Ismailia Governorate. M. Sc. Thesis, Dept. of Zoology, Faculty of Science, Suez Canal University: 207 pp.

MIKHAIL G. 2002. Egypt's biodiversity and the quest for conservation. Image House: $44 \mathrm{pp}$.

MIKHAIL W. Z. A. 1993. Effect of soil structure on soil fauna in a desert wadi in Southern Egypt. J. Arid Environments 24: 321-331.

PAGE A. L., R. H. MILLER, AND D. R. KENNEY. (Ed.) 1982. Methods of soil analysis, part 2 (2nd ed): Chemical and microbial properties, ASA Inc., SSSA Inc. Publisher, Madison, Wisconsin, USA.

POUYAT R. V., K. SZLAVECZ, I. D. YESILONIS, P. M. GROFFMAN, AND K. SCHWARZ. 2010. Chemical, physical, and biological characteristics of urban soils. Book and Multimedia Publishing Committee: $152 \mathrm{pp}$.

RIZK M. A., AND W. Z. A. MIKAIL. 1999. Impact of no-tillage agriculture on soil fauna diversity. Zoology in the Middle East 18 (1).

SEMIDA F. M., M. S. ABDEL-DAYEM, S. M. ZALAT, AND F. S. GILBERT. 2001. Habitat heterogeneity, altitudinal gradients in relation to beetle diversity in South Sinai, Egypt. Egyptian Journal of Biology 3: 137-146.

SOIL QUALITY FACT SHEETS: SOIL ACIDITY. AVAILABLE FROM: THE IUCN RED LIST OF THREATENED SPECIES: OCTOBER 2010 update. Available from: http:// cmsdata.iucn.org /downloads/cycad_factsheet_final.pdf. [Accessed 6 December, 2015].

WINER N. 1999. Egypt's biodiversity. Opportunities and constraints. A report to the United States Agency for International Development, Environment Office, Cairo, Egypt: 13 pp. 


\section{بيئة وبيوجغرافيا الفونا الأرضية في منطقة قتاة السويس}

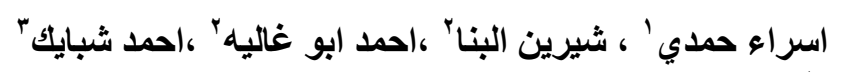

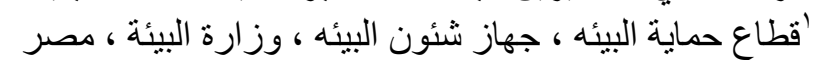

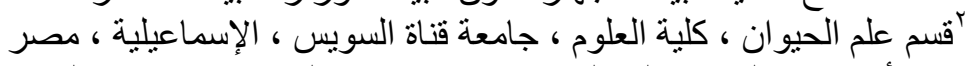

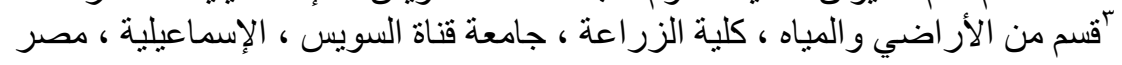

\section{الملخص العربي}

تعتبر الفونا الأرضية من اللافقاريات هي الأكثر تنو عاً بين المجموعات التصنيفية المختلفة وذات أهمية كبيرة في تحقيق سلامة

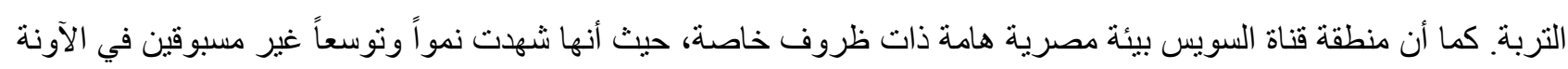

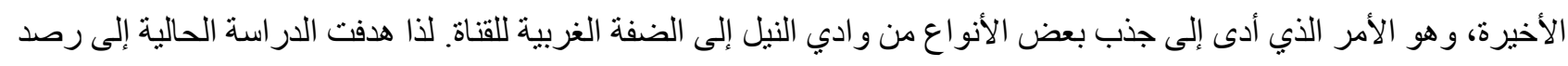
ودراسة نوزيعات الفونا الأرضية فى المنطقة غرب قناة السويس حيث نم اختيار تسعة مو اقع في ثلاث مناطق رئيسية وهى: أبو سلطان وفنارة وجنيفة، وهي تمثل أنشطة بشرية مختلفة وهى مناطق صحر اوية طبيعية ومناطق مزرو عات ومناطق ونات ساحلية تم

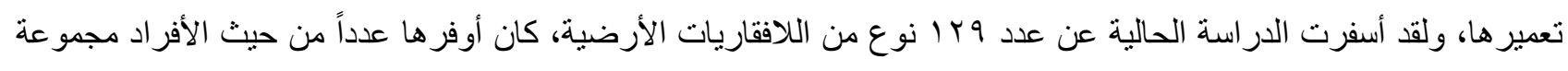
النمل، ومن حيث الأنواع مجموعة الخنافس. كما تبين أن المواقع الصحر اوية هي الأكثر وفرة في أعداد الأفراد و الأقل تضرراً

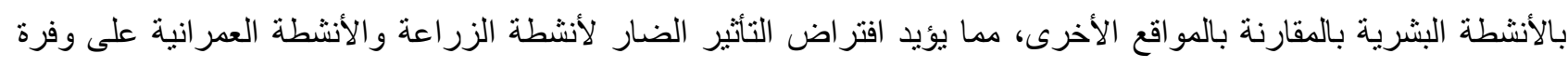
الفونا الأرضية من خلال تغيير خو اص التربة. 